\title{
SOCIAL JUSTICE AND VALORISATION OF OLD AGE PENSIONS IN THE SLOVAK REPUBLIC 2012-20211
}

\author{
doc. PhDr. Richard GEFFERT, Ph.D.
}

\begin{abstract}
Social justice, as one of the key principles of social policy, is the essence of (re)distribution of society's resources in the state. How it is understood and implemented in socio-political and economic practice depends on the axiological orientation of subjects who interpret and implement it. The aim of this paper is to examine how social justice is understood by government groups in the Slovak Republic by means of the valorisation mechanisms for old age pensions over the period 2012-2021.
\end{abstract}

\section{Keywords}

Old Age Pensions, the Slovak Republic, Social Justice, Political Subjects

\section{Introduction}

Justice in mutual human coexistence is the most important moral virtue. It is defined as a firm and unchanging will to give everyone what they deserve (Sutor, 1996). Social justice is one of the fundamental principles of social policy and, it can be said, also of politics in general. Although it is part of every policy, how it is interpreted and applied varies from place to place and time to time. Differences in the understanding of social justice are rooted in historical as well as axiological contexts. In the span of Western civilization, which is identified by the boundaries of the three basic systems - system approach and value legacy of ancient Greece, Christianity; Christian social teaching, modern, postmodern and metamodern political ideologies, social justice has always been understood differently, often diametrically so. Its identification is in direct relation to the form of the state, the type of political system, social structure of society, macro- and micro-economic indicators, customs, traditions, culture, religion, or other form of worldview.

Justice is the opposite of injustice. As a measure of interpersonal relations, it is a fundamental social, religious and moral value, the basis of the rule of law, and also the essence of economic redistribution. It has a broader context in social policy than "only" distributive

1 This paper is part of the solution of the VEGA project 1/0290/20 Social Justice and Old-Age Pension Savings in the Slovak Republic. 
justice. ${ }^{2}$ The two poles of the interpretation and application (primarily in economic practice) are determined by a legal and social framework on the basis of mutual complementarity. A unifying fundamental element is the axiological system of subjects and objects that interpret it in theory and apply it in practice. At the social level, it is defined by the way of redistribution - social welfare. Legal norms are created by people who imprint their own value seal on them. In their understanding, justice is present in time and space. Even in the line of Western civilisation, there is no generally accepted definition of social justice. In a democratic political system, the boundaries of the definition of its meaning can be tied to the value systems of entities exercising political power. From the aspect of the hierarchical level of the place of implementation, this may be at the supranational, national, regional or local level. The value orientation remains relatively stable at all these levels. As for the evaluation of the social status of an individual or a monitored social group, this situation can be understood as fair because it is given by fate, god, inheritance of social status, work performance. The current social status of objects and subjects is always given by a synthesis of several factors. In reflecting social justice from subjects to objects, three basic (but not the only) streams of values can be defined in a democracy. On the one hand, there is the complex of conservative - liberal streams; right-wing values, in which state intervention in the redistribution of resources is minimal. If it does intervene, so then it does so only indirectly, leaving this primarily to the market and its tools. The opposite is a complex of socialist and social-democratic values, in which the state is the dominant entity that significantly intervenes in the redistribution of resources. The essence of the third so-called "middle system" of values lies in balancing state and market interventions in the redistribution of economic resources. This approach is not applicable to political systems that are characterised by extreme value systems on the right wing - left-wing scale, for example communism, or libertarianism.

Social justice and harmony are fundamental to the legality and legitimacy of government. Each political party (political entity) ${ }^{3}$ declares that society should be organised, structured and managed on the basis of the principle of social justice. Social justice and social inequalities have a strong normative content. The question "how is it divided, who gets or does not get what, and for what" raises the question "what they should get and why" 4 - the normative criterion, which means that the perception of social justice and social inequalities is exposed to the influence of both internal and external circumstances. At the axiological level, social

2 The philosophical value tradition of Western civilisation distinguishes three specific forms of justice, which correspond to the three basic relationships necessary for human existence. Commutative justice - Justice of exchange or social relations, also called justice of contractual arrangements, which concerns the relations of groups and persons with one other. Legal justice - The justice of laws relates to the ratio of persons and groups to the social whole. Distributive justice - the justice of distribution or allocation concerns the whole, or its representatives to individuals and groups, for detail see SUTOR, Bernard: Political Ethics. OIKOYMENH, Prague 1996, 384.

3 The past decade saw a fundamental developmental change occurring in political actors on the morphing political scene of the states of Western civilisation. Classical political parties are today in most cases being replaced by other political entities. These do not fulfil even the basic features characteristic of political parties. In this sense, it may be said that there is a gradual replacement of patronage with a new model of the political system.

4 In life as well as in politics, there is always a difference between what is and what should be. What is, only exceptionally, is what should be. We should strive to achieve what should be. 
justice is a popular part of the political agenda of every political entity, but, quite naturally, it is interpreted differently. In connection with this, the state, as the basic subject of social policy, is perceived by the left as a socially just policy based on a broad redistribution of public resources, in comparison with the liberal-conservative centre-right political span, which puts this phenomenon more on a level based on individual merit in economic processes, while weakening the influence of the state at the level of redistribution. A fundamental question arises here as regards how to understand the efficiency and effectiveness of social justice interpreted in these different ways. It might seem that a shift in language on the state and market scale leads to a weakening of the phenomenon of social justice in terms of its impacts on individuals and target social groups. But is this really true? In social policy, equally as in other policy areas, the feedback effect is at work. A stricter understanding of redistribution can positively strengthen the functioning of economic processes, which in turn beneficially may be expressed in a growing standard of living for the population, increasing motivation.

Every model of social policy contains a certain understanding of social justice. The mechanisms, methods and degree of ensuring social and economic rights are always an important moment. The concept of social citizenship is the core of the welfare state. ${ }^{5}$ In Western civilisation, one can start from the basic typology of social policy by R. Titmuss, which is reflected in all social events. It is identified on the basis of the degree of state involvement in social policy and in enabling the participation of private entities. These are redistributive, corporate and residual models. In terms of valorisation of old age pensions, three limit models of the mechanism for their valorisation may also be considered. In the first case, this is an across-the-board increase in the set amount of the old age pension, preferred by the centre-left political representation. This model of valorisation in the understanding of social justice can be supplemented/ combined by a declining fixed amount with an increasing amount of the old age pension. The second model is characterised by a percentage increase in the amount of the old age pension, which is based on performance, i.e. Merit or service, taking account of the lifelong effort and responsibility of the social object in relation to the old age pension ex ante. This model is preferred by political entities positioned in the centre right of the political spectrum. The third model is a combination of the first two, where the amount of the old age pension is valorised partly by a fixed amount and partly by a percentage (according to the advantageousness for the basic object - the old age pensioner, but also the subject, and thus also the state). These models are a result of the implementation of the understanding of social justice in the old age pension system of Western civilisation. They are always only models, which in reality are never implemented in an absolute form. At the same time, it can be stated that even in this case, each state implements its own model, which is the result of several factors, such as economic indicators, historical development, traditions, culture, religion, mentality of the population, etc. Real pension systems change and develop in different places over time. In today's globalised world, both monetary and fiscal are also interconnected.

A number of authors are focusing on the systematic study of social justice in the current globalised world. In the context of building, but also reforming, the old age pension system, for the demographic and related economic, social and humanitarian reasons outlined above,

5 RADIČOVÁ, Iveta: Sociálna politika na Slovensku, SPACE 1998, 244. 
we can mention, for example, the authors and their works: Heikki Oksanen (2002) "Pension reforms: key issues illustrated with an actuarial model", Erik Schokkaert and Philippe Van Parijs (2003) "Debate on Social Justice and Pension Reform: Social Justice and the Reform of Europe's Pension Systems", Alan Walker (2003) "The Policy Challenges of Population Ageing", David Willetts (2003) "Old Europe? Demographic change and pension reform", Grégory Ponthière (2020) "Pensions and social justice. From standard retirement to reverse retirement." The fact that this is a global, not just local, problem we are permanently dealing with adequately or inadequately in Western civilisation is proven by a spectrum of authors focusing on this issue in all parts of the world. Patrik Marier and Jean. F. Mayer (2007) "Welfare Retrenchment as Social Justice: Pension Reform in Mexico", M. R. Narayana (2019) "Old Age Pension Scheme in India: Distributional Impacts", Paul-Sewa Thovoethin, Jobson O. Ewalefoh (2018) "Universal old-age pension: Can Africa overcome it's challenges?", Evelyne Huber, John D. Stephens (2000) "The Political Economy of Pension Reform: Latin America in Comparative Perspective", Mesa-Lago Carmelo (2014) "Reversing pension privatization. The experience of Argentina, Bolivia, Chile and Hungary."

It is also necessary to mention the fact that, according to ILO statistics, only $85 \%$ of the world's population currently has social security. Despite this, the efforts of international communities at various levels and from various platforms dealing with this issue over the long term can be commended, as evidenced by the outputs of, for example, the UN: Fernando Filgueira and Pilar Manzi (2017) "Pensions and income transfers for old age. Interand intra-generational distribution in comparative perspective", or the ILO documents: (2014) "Social policy for older people: Key policy trends and statistics", Camila Arza from UN Woman (2015) "The gender dimensions of gender systems. Policies and constraints for the protection of older women."

The field of the Slovak old age pension system, its necessary reform in a rapidly changing world in the context of individual disciplines, but also in terms of understanding the social justice of its objects in a broader or narrower sense is mapped by the works of several authors, such as: Kenichi Hirose (2011) "Pension reform in Central and Eastern Europe. In time of crisis, austerity and beyond", Ivan Lesay (2006) "Pension reform in Slovakia, the context of economic globalization", Bačová, V., Dudeková, K., Kostovičová, L., Baláž., V. (2017) "Financial Planning for Retirement in Young Adults: Interaction of Professional Experience", Bačová, V. and Kostovičová, L. (2018) "Too Far Away to Care About? Predicting Psychological Preparedness for Retirement Financial Planning among Young Employed Adults", Baláž, V. (2012) "Financial literacy in the context of active aging - survey results", Košta, J. (2017) "Možnosti riešenia rizík vo financovaní dôchodkového systému s ohladom na príjmové nerovnosti", or Kusá, Z. (2016) "Predstavy o spravodlivej spoločnosti. Prvý pohlad na zistenia fókusových skupín k Výskumu európskych hodnôt EVS 2017 - Slovensko", etc.. On the issue of social justice in the old age pension system in the axiological context in the relationship between political subjects - models of social policy, the space for further theoretical and empirical analyses remains permanently open. 


\section{Social justice in the old age pension system of the Slovak Republic}

With regard to the perception of social justice in application to political representation in the Slovak Republic over the observed period 2012-2021, this can be schematically captured and monitored via a mechanism of valorisation (or indexation) of old age pensions. As indicated, each political representation, the governing coalition, implements its own line of economic and social policy. ${ }^{6}$ During the observed period, three or four government representations alternated in the government of the Slovak Republic. The results of the parliamentary elections and the composition of each Slovak government are described in greater detail in table 1.

6 The paper follows one of the main principles of social policy, but this is always utilitaristically connected with economic policy. It represents the creation of resources by which subjects deal with social events through redistribution. 
Table 1 SR Governments 2012-2021

\begin{tabular}{|c|c|c|c|c|c|}
\hline $\begin{array}{l}\text { Term } \\
\text { of office }\end{array}$ & $\begin{array}{l}\text { Governing } \\
\text { coalition } \\
\text { subjects }\end{array}$ & Votes \% & \begin{tabular}{|c|} 
Seats \\
SR \\
Parliament
\end{tabular} & $\begin{array}{c}\text { Coalition } \\
\text { seats } \\
\text { total }\end{array}$ & $\begin{array}{l}\text { value orientation } \\
\text { of subject } \\
\text { political spectrum }\end{array}$ \\
\hline $\begin{array}{l}2012-2016 \\
(10.03 .2012)\end{array}$ & SMER-SD & 44.41 & 83 & 83 & $\begin{array}{l}\text { social democracy, } \\
\text { political left, strong } \\
\text { standing of state }\end{array}$ \\
\hline $\begin{array}{l}2016-2020^{7} \\
(05.03 .2016) \\
2018-2020^{8} \\
(05.03 .2016)\end{array}$ & $\begin{array}{l}\text { SMER-SD } \\
\text { SNS } \\
\text { MOST-HÍD } \\
\text { \#SIET'9 }\end{array}$ & $\begin{array}{l}6.50 \\
5.60\end{array}$ & $\begin{array}{l}49 \\
15\end{array}$ & 85 & $\begin{array}{l}\text { social democracy, } \\
\text { political left, } \\
\text { strong standing } \\
\text { of state } \\
\\
\text { Social right to far } \\
\text { right Economically - } \\
\text { centre-left, national } \\
\text { conservatism } \\
\text { Centre-right, national } \\
\text { conservatism } \\
\text { Centrism, liberal } \\
\text { conservatism }\end{array}$ \\
\hline $\begin{array}{l}2020-2024 \\
(29.02 .2020)\end{array}$ & $\begin{array}{l}\text { OL'ANO } \\
\text { SME } \\
\text { RODINA } \\
\text { SaS } \\
\text { ZA L'UDÍ }\end{array}$ & $\begin{array}{l}25.02 \\
8.24 \\
6.22 \\
5.77\end{array}$ & $\begin{array}{l}53 \\
17 \\
13 \\
12 \\
12\end{array}$ & 95 & $\begin{array}{l}\text { a broad people's } \\
\text { political entity, } \\
\text { conservatism } \\
\text { national conservatism, } \\
\text { social conservatism } \\
\text { right-wing, national } \\
\text { liberalism, } \\
\text { classical liberalism } \\
\text { centrism, conservative } \\
\text { liberalism } \\
\end{array}$ \\
\hline
\end{tabular}

Source: SR Statistical Office 2012-2020.10 Election programmes of political entities 2012-2020.

7 The government, which emerged from the elections in 2016, resigned on 15 March 2018, see: The President accepted the resignation of the Prime Minister and appointed Peter Pellegrini, online: https://www.prezident.sk/ article/prezident-prijal-demisiu-predsedu-vlady/ (Downloaded 23. March 2021).

8 The new reconstructed government received the support of the SR Parliament on 26 March 2018, see: NR SR: Mr Pellegrini's government one vote of confidence, supported by 81 deputies. online: https://www.nrsr.sk/web/ Default.aspx?sid=udalosti/udalost\&MasterlD=54596 (Downloaded 24 March 2021).

9 The political entity \#SIET broke up back in 2016; the majority of parliamentary deputies joined the MOST-HÍD club.

10 Elections and referendums, online: https://volby.statistics.sk/ (Downloaded 23. March 2021). 
Valorisation ${ }^{11}$ of old age pensions is an economic instrument conducted in the Slovak Republic on 1 January of the calendar year. Its preparation is related to the preparation of the state budget for the following calendar year.

In the period from 2012 to 2016, the single-colour government of the political party SMER-SD seized political power in the Slovak Republic, ${ }^{12}$ which unusually in the system of parliamentary democracy in the multi-party political system, gained $44.41 \%$ of votes in the elections to the SR Parliament, meaning 83 seats. The single-colour government enabled this political entity to fully implement its understanding of social policy also in the field of the valorisation of old age pensions. This political entity, in terms of its values, represents the political left, which prefers dominance of the state over the private sector. The centre-left understanding of social justice, with the state holding a dominant position in dealing with social events was also fully reflected in the mechanism for valorisation of old age pensions. With effect from 1 January 2013, the flat-rate method of valorisation of old age pensions by a fixed amount was applied, on the basis of Act of Parliament no. 461/2003 Coll. on social insurance and on the amendment of certain acts. According to the data of the Social Insurance Agency in the period from 2013 to 2017, pension benefits increased by a fixed amount. The fixed amount of the increase in pension benefits depended on the year-on-year growth in consumer prices, and the year-on-year growth in the average wage in the Slovak economy. These were reported by the Statistical Office of the Slovak Republic for the first half of the calendar year preceding the calendar year for which the pension benefits were increased and from the average monthly amount of individual pension benefits reported by the Social Insurance Agency on 30 June of the calendar year preceding the calendar year for which the pension benefits were increased. The fixed amounts of the increase in pension benefits and the fixed amounts of the increase in pension benefits paid out in the amount of one half for reason of the overlapping entitlements to payment of pension benefits, were set out in 2013-2017 as follows:

11 Valorisation is distinct from indexation. Valorisation represents an increase in the real value of the monetary benefit, while indexation is an increase in the nominal value of the monetary benefit, for more see: GEFFERT, Richard: Sociálna politika a jej axiologické orientácie, Košice 2014, 158.

12 For a comparison of the value systems in the area of models of the old age pension system, it is useful to note also the government coalition, which held government in the Slovak Republic up to 2012. This was a coalition (2010 - 2012) of centre-right political entities: SDKÚ-DS, SAS, KDH and MOST-HÍD, see: Elections and referendums, online: https://volby.statistics.sk/ (Downloaded 24. March 2021). 
Table 2 Valorisation of old age pensions in the Slovak Republic 2013-2017

\begin{tabular}{|l|c|c|c|c|c|}
\hline $\begin{array}{l}\text { Year } \\
\text { valorisation }\end{array}$ & $\mathbf{2 0 1 3}^{13}$ & $\mathbf{2 0 1 4 ^ { 1 4 }}$ & $\mathbf{2 0 1 5 ^ { 1 5 }}$ & $\mathbf{2 0 1 6}^{\mathbf{1 6}}$ & $\mathbf{2 0 1 7 ^ { 1 7 }}$ \\
\hline $\begin{array}{l}\text { old age } \\
\text { pension }\end{array}$ & $11.20 €$ & $8.80 €$ & $5.20 €$ & $1.90 €$ & $8.40 €$ \\
\hline $\begin{array}{l}\text { early } \\
\text { old-age } \\
\text { pension }\end{array}$ & $11.50 €$ & $8.90 €$ & $5.30 €$ & $1.90 €$ & $8.20 €$ \\
\hline $\begin{array}{l}\text { the old age } \\
\text { pension/1/2 }\end{array}$ & $3.50 €$ & $2.70 €$ & $1.60 €$ & $0.60 €$ & $2.60 €$ \\
\hline $\begin{array}{l}\text { early } \\
\text { old-age } \\
\text { pension } \\
\mathbf{1 / 2}\end{array}$ & $4.10 €$ & $3.30 €$ & $1.90 €$ & $0.70 €$ & $€ 3.00$ \\
\hline
\end{tabular}

Source: Social Insurance Agency 2013-2017.

As regards 201718, according to an amendment to Act 461/2003 Coll. on social insurance, from 1 January 2017, old age pensions were increased by an amount calculated as $2 \%$ of the average old age pension, i. e. in the range from $€ 8.20$ to $€ 8.40$.

The parliamentary elections in the Slovak Republic in 2016 meant the redistribution of power from the one-color government of the SMER-SD party, as a representative of the political left to the new government four-party coalition consisting of SMER-SD, SNS, MOST-HÍD and \#SIET. The three new governing political entities can be characterised at the axiological level on the basis of an analysis of their political programmes as centreright. In the range of values from centre to right, they can be arranged as follows from the centre - MOST-HÍD, \#SIET and SNS. The value orientation of the monitored entities in the right part of the political spectrum was clearly reflected in the understanding of the position of the state and the private sector in the implementation of old age pension valorisation mechanisms. In addition to addressing other social events in the area

13 The head office of the Social Insurance Agency provides the information online: https://www.socpoist.sk/ aktuality/54309c (Downloaded 24 March 2021).

14 The head office of the Social Insurance Agency provides the information online: https://www.socpoist.sk/ aktuality/56314c (Downloaded 24 March 2021).

15 The head office of the Social Insurance Agency provides the information online: https://www.socpoist.sk/ aktuality/59205c (Downloaded 24 March 2021).

16 The head office of the Social Insurance Agency provides the information online: https://www.socpoist.sk/ aktuality-ako-sa-zvysia-dochodky-v-roku-2016--o-zvysenie-netreba-ziadat/ (Downloaded 24 March 2021).

17 The head office of the Social Insurance Agency provides the information, online: https://www.socpoist.sk/ aktuality-ako-sa-zvysia-dochodky-v-roku-2016--o-zvysenie-netreba-ziadat/ (Downloaded 24 March 2021).

18 The head office of the Social Insurance Agency provides the information online: https://www.socpoist.sk/ aktuality/54309c (Downloaded 24 March 2021). 
of old age pensions, a new valorisation mechanism was applied, entailing a weakening of the state, in the sense of an across-the-board increase in pension benefits to increase personal responsibility of entities during one's economically active life in relation exante to old age pensions. In $2018^{19}$ the valorisation method for old age pensions (as well as other benefits) was significantly changed. The new mechanism of increasing pensions results from an amendment to Act 461/2003 Coll. on social insurance, passed by the SR Parliament on 19 October 2017. From 1 January 2018, old age pensions increased by $0.8 \%$ of the monthly amount of pensions, but at least by a fixed amount (listed in the table below by type of pension), which is determined as 2 percent of the average monthly amount of pensions reported by the Social Insurance Agency as at 30 June 2017. ${ }^{20}$

\section{Table 3 Valorisation of old age pensions in the Slovak Republic at least by a fixed sum 2018-2021.}

\begin{tabular}{|l|c|c|c|c|}
\hline $\begin{array}{l}\text { Year } \\
\text { valorisation }\end{array}$ & $\mathbf{2 0 1 8}^{21}$ & $\mathbf{2 0 1 9 ^ { 2 2 }}$ & $\mathbf{2 0 2 0 ^ { 2 3 }}$ & $\mathbf{2 0 2 1 ^ { 2 4 }}$ \\
\hline $\begin{array}{l}\text { old age } \\
\text { pension }\end{array}$ & $8.40 €$ & $8.70 €$ & $9.00 €$ & $9.40 €$ \\
\hline $\begin{array}{l}\text { early } \\
\text { old-age } \\
\text { pension }\end{array}$ & $8.20 €$ & $8.30 €$ & $8.70 €$ & $9.10 €$ \\
\hline $\begin{array}{l}\text { the old age } \\
\text { pension/1/2 }\end{array}$ & $2.60 €$ & $2.70 €$ & $2.70 €$ & $2.90 €$ \\
\hline $\begin{array}{l}\text { early } \\
\text { old-age } \\
\text { pension } \\
\text { 1/2 }\end{array}$ & $3.00 €$ & $3.00 €$ & $3.20 €$ & $€ 3.30$ \\
\hline
\end{tabular}

Source: Social Insurance Agency 2018-2021.

19 In 2018, from 18 March the SR Government was reconstructed. With the Prime Minister replaced, a new government was formed, which appeared before the Slovak Parliament with a request for a vote of confidence. Mr Pellegrini's newly-formed government essentially respected the results of the 2016 parliamentary elections, and the new government programme statement of 2018 also copied that of 2016. The new government (20182020) did not violate the redistribution of the value theses of the 2016-2018 government, and thus also in the area of social insurance, valorisations of old age pensions were conducted according to the percentage key.

20 The Social Insurance Agency, online: https://www.socpoist.sk/aktuality/54309c (Downloaded 24 March 2021).

21 The head office of the Social Insurance Agency provides the information, online: https://www.socpoist. sk/3077-aktuality/48411s65096c (Downloaded 24 March 2021).

22 The head office of the Social Insurance Agency provides the information, online: https://www.socpoist.sk/ aktuality-valorizacia-dochodkov-od-1-januara-2019/48411s66866c? (Downloaded 24 March 2021).

23 Increasing pensions in 2020 online: https://www.socpoist.sk/zvysenie-dochodkov-v-roku-2020/68032s (Downloaded 24 March 2021).

24 Calculator for calculating the pension valorisation from 1 January 2021 online: https://www.socpoist.sk/ kalkulacka-na-vypocet-valorizacie-dochodku-od-1-januara-2021/68030s (Downloaded 24 March 2021). 


\section{Table 4 Average amounts of pension benefits for the needs of valorisation (as at 30.6.).}

\begin{tabular}{|l|c|c|c|}
\hline year & $\mathbf{2 0 1 8}$ & $\mathbf{2 0 1 9}$ & $\mathbf{2 0 2 0}$ \\
\hline old age pension & 432.7650665 & 449.9720304 & 468.1733788 \\
\hline $\begin{array}{l}\text { Early old age } \\
\text { pension }\end{array}$ & 413.4832766 & 434.9960174 & 451.6934628 \\
\hline
\end{tabular}

Source: Social Insurance Agency 2017.25

The valorisation of all types of pensions in 2019, including old age pensions, is based on data on year-on-year growth in consumer prices for pensioner households for the first half of 2018. According to data from the Statistical Office of the Slovak Republic reported this figure was $2.6 \%$. This means that pension benefits increased in 2019 either by $2.6 \%$ or by the minimum valorisation fixed amount of the given type of pension, whichever was the more advantageous for the old age pensioner. The amount of the increase in the old age pension in 2019 was at least a fixed amount of $€ 8.70$ for old age pensions and $€ 8.30$ for early old age pensions. The amount of the increase in the pension paid in the amount of one half was $€ 2.70$ for the old age pension and $€ 3.00$ for the early retirement pension. ${ }^{26}$ As regards 2020, here the Social Insurance Agency increased old age pensions in the year according to Section 82 and Section 293dx of Act no. 461/2003 Coll. on social insurance, as amended, by $2.9 \%$ of the monthly amount of pensions, at least, though, in the fixed amount determined as $2 \%$ of the average monthly sum of individual types of pensions reported by the Social Insurance Agency as at 30 June 2019. The guaranteed, and therefore fixed, amounts of the increases in 2020 were as follows. In the case of an old age pension in the full amount of $€ 9$, the amount of the pension increase paid out in the amount of one half represented $€ 2.70$. In the case of an early retirement pension, this was the value of $€ 8.70$, the amount of the pension increase paid out in the amount of one half was $€ 3.20$. The valorisation of old age pensions for 2020 was prepared by the government comprising the entities SMER-SD, SNS, MOST - HÍD (centre-left value orientation) and the valorisation for 2021 was then under the direction of the new government, which currently consists of the subjects OL'ANO, SME RODINA, SaS and ZA L'UDÍ (Table 1). In the given period since the start of 2020, the Covid-19 pandemic has significantly affected the overall economic and social situation, which has required and still does require extremely high investment in research, development and the implementation of solutions to this serious problem. Part of the pre-election struggle was also the topic of 13th pension in the Slovak Republic, which was partly reflected in the socio-economic reality already in December 2020. It is this moment that can be understood as key in identifying the understanding of social justice in the period observed.

Over the period 2020 to 2021 two government coalitions alternated in power in the Slovak Republic in the standard term of parliamentary elections. As mentioned above, up until

25 The Social Insurance Agency, online: https://www.socpoist.sk/aktuality/54309c (Downloaded 24 March 2021).

26 Social Insurance Agency, online: https://www.socpoist.sk/aktuality-valorizacia-dochodkov-od-1-januara-2019/ 48411s66866c? (Downloaded 24 March 2021). 
30.4.2020 power was held by a coalition of SMER-SD, SNS, MOST - HÍD. On 29.2.2020 the Parliamentary elections were held, in which the political entities OL'ANO, SME RODINA, SaS and ZA L'UDÍ succeeded, forming a government coalition. This political cooperation resulted on 30.4.2020 in the formation of a government coalition and, on the basis of an expression of confidence and approval of the Government's programme statement 2020-2024 by the Parliament of the Slovak Republic they took over the creation and implementation of political power in the state.

The solution for the increase in old age pensions was in the competence of the new centreright government representation in the year. In January 2021, more than 1.4 million old age pensioners received more money. ${ }^{27}$ In January 2021, pension benefits were increased (table 3) either by a percentage of the year-on-year increase in consumer prices for pensioner households, i. e. by the so-called pensioner inflation, or by the minimum valorisation fixed amount pertaining to the given kind of pension. Year-on-year growth in consumer prices for the first half of 2020, based on data published by the Statistical Office, was $2.6 \%$. More than 1.51 million pensions, out of more than 1.7 million pensions paid, grew by the pensioner inflation, i. e. by $2.6 \%$ of the monthly pension amount. For almost $87 \%$ of pensioners, percentage valorisation was more advantageous. ${ }^{28}$

Another moment on the basis of which it is possible to observe which model of old age pension valorisation is preferred by which political subject through its axiological system is the institute of the 13th pension. The discussion, especially political-populist on the issue, has been going on for several years. It is demonstrable that while the centre-left political representation prefers a uniform amount of the 13th pension for all categories of old age pensioners, the centre-right part of the political spectrum supports the 13th pension on the basis of the classical percentage model based on performance and merit.

If we follow the institute of the 13th pension in the Slovak Republic I refer the time period 2012-2021, it can be said that valorisation in the form of the 13th old age pension took place essentially only once, in the following form. In 2020, SMER-SD promoted again in 2020 the 13th pension in a uniform amount of $€ 460$, whilst early retirees were to receive $€ 433$. This amount was based on the average pension. The legislation for this model received support from SMER-SD, SNS and SME RODINA. However, as follows from the above, parliamentary elections were held in the Slovak Republic on 29 February 2020, and the government coalition composed of OL'ANO, SME RODINA, SAS and ZA L'UDÍ intervened in the form of implementation of the institute of the 13th pension in December 2020. The actual model of the 13th pension in the Slovak Republic in 2020 was as follows: The maximum amount of the 13th pension in 2020 was $€ 300$. This was paid to pensioners with a pension of $€ 214.83$ or less. For recipients of a pension in the range from $€ 214.84$ to $€ 909.27$ the amount the 13th pension was reduced down to a minimum of $€ 50.01$.

27 It is pertinent to ask whether more money in 2021 also means higher real purchasing power. This question is connected also with the target group of old age pensioners, as well as all other social groups. The process of massive quantitative easing again in 2021 meant a negative development of multiple economic indicators, for example inflation, which significantly affects the real value of money. It is also questionable whether this constitutes valorisation or indexation, but we also have in mind here the global perspective, the Bretton Woods monetary system, which though, is not directly a subject of examination in this paper.

28 The head office of the Social Insurance Agency provides the information, online: https://www.socpoist.sk/ aktuality-ako-sa-zvysia-dochodky-v-roku-2021/48411s69059c (Downloaded 24 March 2021). 
The lowest 13th pension in the amount of $€ 50$ is paid to those pensioners who received a pension in the amount from €909.28 or more. ${ }^{29}$

Since January 2021, there has been an amendment to Act no. 461/2003 Coll. on social insurance. Under this amendment, the amount of the minimum old age pension has remained at the level from 2020. The SR Parliament passed a return to the conditions of qualified years, as well as earnings at least at the level of $24 \%$ of the average wage. A recipient of the minimum pension whose pension was, even after the January valorisation, lower than the statutory minimum pension receives a pension in an unchanged amount, for reason of "preserving the minimum pension". From the beginning of the 2021 calendar year, the legislative amendment allows for the setting of the minimum pension amount to be re-evaluated only after those periods of pension insurance that are considered qualified. Thus, in terms of a pension's applicant entitlement to a minimum pension, there are again considered only those years of pension insurance in which the applicant earned in close monthly at least $24.1 \%$ of the average wage, i. e. a little less than $€ 274$. The amount of the minimum pension for 30 years of a qualified pension insurance period thus remains at $€ 334.3$ monthly. The amount of the minimum pension may be increased again only once an amount representing $136 \%$ of the amount of the subsistence minimum for one adult natural person exceeds the amount of $€ 334.30$. Seemingly, the minimum pension amounts will be frozen for the next 12 years. The Ministry of Labour, Social Affairs \& Family of the Slovak Republic has proposed freezing the nominal amounts of the minimum pension to the level of 2020, due to the introduction of justice and the adjustment of conditions for the provision of the minimum pension, and its fair valorisation. ${ }^{30}$

\section{Conclusion}

The aim of this paper has been to address the understanding of social justice by government groups in the Slovak Republic through the mechanisms of valorisation of old age pensions in the period 2012-2021. The objective of the study to highlight the fact that the axiological basis and models of social policy can serve as a key to understanding the essence and implementation of specific political steps of government representations, made it possible to emphasise the lasting significance of values in political practice. It was confirmed that the classical typology of social policy is relevant also in the case of monitoring valorisation mechanisms applied by individual government coalitions, and this also in the Slovak Republic, which is part of the span of Western civilisation with its axiological basis. As has been proven, the value orientations of non-classical political entities, which currently represent the dominant part of the political spectrum, essentially correspond to the value lines of traditional political entities, now currently in decline. It remains relevant that left-wing political subjects perceive social justice through a dominant standing of the state, which is reflected in an across-the-board raising of old age pensions. Right-wing political subjects emphasise lifelong work performance and merit, which should

29 The head office of the Social Insurance Agency provides the information, online: https://www. socpoist.sk/aktuality-socialna-poistovna-dnes-zacina-vyplacat-13-dochodok--dostane-ho-priblizne-1-4-mildochodcov/48411s69131c (Downloaded 24 March 2021).

30 Pension by design, online: http://pensionbydesign.com/\# (Downloaded 24 April 2021). 
also be reflected in the valorisation mechanism for the old age pension via a percentage increase. The value basis of the policy is a historically stable indicator that still resists various changes, even at this time, which is characterised by the building of a new metamodern ${ }^{31}$ globalised world.

\section{References}

\section{Legal sources}

Kalkulačka na výpočet valorizácie dôchodku od 1. januára 2021 online:

https://www.socpoist.sk/kalkulacka-na-vypocet-valorizacie-dochodku-od-1-januara2021/68030s (Downloaded 24 March 2021).

NR SR: Vláda P. Pellegrinoho získala dôveru, podporilo ju 81 poslancov. online: https:// www.nrsr.sk/web/Default.aspx?sid=udalosti/udalost\&MasterlD=54596 (Downloaded 24 March 2021).

Pensionbydesign, online: http://pensionbydesign.com/\# (Downloaded 24 April 2021).

Prezident prijal demisiu predsedu vlády a poveril Petra Pellegriniho, online: https://www.prezident.sk/article/prezident-prijal-demisiu-predsedu-vlady/ (Downloaded 23. March 2021).

Sociálna poistovňa, online:https://www.socpoist.sk/priemerne-vysky-dochodkovych-davokpre- potreby-valorizacie--k-306-/56026s (Downloaded 23. March 2021).

Sociálna poistovnna, online:https://www.socpoist.sk/priemerne-vysky-dochodkovych-davokpre-potreby-valorizacie---k-306-/56026s (Downloaded 24 March 2021).

Ústredie Sociálnej poistovne informuje, online: https://www.socpoist.sk/aktuality/54309c (Downloaded 24 March 2021).

Ústredie Sociálnej poist́ovne informuje, online:

https://www.socpoist.sk/aktuality/56314c (Downloaded 24 March 2021).

Ústredie Sociálnej poistovne informuje, online: https://www.socpoist.sk/aktuality/59205c (Downloaded 24 March 2021).

Ústredie Sociálnej poist'ovne informuje, online: https://www.socpoist.sk/aktuality-ako-sazvysia-dochodky-v-roku-2016--o-zvysenie-netreba-ziadat/ (Downloaded 24 March 2021).

31 See more: KADAGISHVILI, Dali: Metamodernism as we perceive it, in: An International Journal, 2013 (2), $559-565$. 
Ústredie Sociálnej poistovne informuje, online: https://www.socpoist.sk/aktuality-ako-sazvysia-/48411s62787c (Downloaded 24 March 2021).

Ústredie Sociálnej poist́ovne informuje, online: https://www.socpoist.sk/aktualityvalorizacia-dochodkov-od-1-januara-2019/48411s66866c? (Downloaded 24 March 2021).

Ústredie Sociálnej poistovne informuje, online: https://www.socpoist.sk/aktuality-ako-sazvysia-dochodky-v-roku-2021/48411s69059c (Downloaded 25 March 2021).

Vol'by a ref Zákon č. 461/2003 Z. z. o sociálnom poistení v znení neskorších predpisov a ktorým sa menia a doplńajú niektoré zákony, online: https://www.socpoist.sk/zakon-osocialnom-poisteni-c-461-2003-z-z-vzneni-neskorsich-predpisov/697s (Downloaded 17. 04. 2021).

Zvýšenie dôchodkov v roku 2020 online: https://www.socpoist.sk/zvysenie-dochodkov-v roku-2020/68032s (Downloaded 24 March 2021).

Vol'by a referendá, online: https://volby.statistics.sk/ (Downloaded 23. March 2021).

ARZA, Camila: The gender dimensions of gender systems. Policies and constrainst for the protection of older women, online: https://socialprotection-humanrights.org/wpcontent/uploads/2015/08/ARZA-Fin.pdf (Downloaded 15 April 2021).

BAČOVÁ, Viera - DUDEKOVÁ, Katarína - KOSTOVIČOVÁ, Lenka - BALÁŽ, Vladimír: Financial Planning for Retirement in Young Adults: Interaction of Professional Experience, in: Psychologica Studia, 59, 2017, 2, 84-99.

BAČOVÁ, Viera - KOSTOVIČOVÁ, Lenka: Too Far Away to Care About? Predicting Psychological Preparedness for Retirement Financial Planning among Young Employed Adults, in: Ekonomický časopis/Journal of Economics, 66, 2018, 1, 44-63.

BALÁŽ, Vladimír: Finančná gramotnost'v kontexte aktívneho starnutia - výsledky prieskumu, in: Ekonomický časopis/Journal of Economic, 60, 2012, 7, 681-697.

CARMELO, Mesa-Lago: Reversing pension privatization. The experience of Argentina, Bolivia, Chile and Hungary, in: ILO ESS Working Papers, 44, 2014, 1-31.

FILGUEIRA, Fernando - PILAR, Manzi: Pension and income transfers. Inter-and Intragenerational distribution in comparative perspective, in: Social Policy Series, 225, 2017, 7-67.

GEFFERT, Richard: Sociálna politika a jej axiologické orientácie, Košice 2014,158.

HIROSE, Kenichi: Pension reform in Central and Eastern Europe. In time of crisis, austerity and beyond, ILO 2011, 338. 
HUBLER, Evelyne - STEPHENS, John D.: The Political Economy of Pension Reform: Latin America in Comparative Perspective, in: UNRISD Occasional Paper, 7, 2000, 7-39.

KADAGISHVILI, Dali: Metamodernism as we percieve it, in: European Scientific Journal, 2013, 2, 559-565.

KOŠTA, Ján: Možnosti riešenia rizík vo financovaní dôchodkového systému s ohladom na príjmové nerovnosti, in: Working Papers, SAV, 93, 2017, 35.

KUSÁ, Zuzana: Predstavy o spravodlivej spoločnosti Prvý pohlad na zistenia fókusových skupín k Výskumu európskych hodnôt EVS 2017 - Slovensko, online: http://www.sociologia. sav.sk/pdf/Working_Papers_in_Sociology_022016.pdf (Downloaded 17. April 2021).

LESAY, Ivan: Pension reform in Slovakia, the context of economic globalization, online: https://www.etui.org/sites/default/files/06\%20Pension\%20reform\%20in\%20Slovakia.pdf (Downloaded 17. April 2021).

MARIER, Patrik - MAYER, Jean F.: Welfare Retrenchment as Social Justice: Pension Reform in Mexico, in: Journal of Social Policy, 36, 2007, 4, 585-604.

NARAYANA, Murthy: Old Age Pension Scheme in India: Distributional Impacts, in: South Asia Research, 39, 2019, 2, 143-165.

OKSANEN, Heikki: Pension reforms: key issues illustrated with an actuarial model, in: European Economy. Economy Papers, 174, 2002, 3-60.

PONTHIÉRE, Grŕgory: Pensions and social justice. From Standard Retirement to Reverse Retirement, PSE Working Papers 2020, 26.

RADIČOVÁ, Iveta: Sociálna politika na Slovensku, SPACE 1998, 244.

SOCIAL PROTECTION POLICY PAPERS. Social policy for older people: Key policy trends and statistics, online: https://www.ilo.org/wcmsp5/groups/public/---dgreports/---dcomm/ documents/publication/wcms_310211.pdf (Downloaded 15 April 2021).

SCHOKKAERT, Erik - VAN PARIJS, Philippe: Debate on Social Justice and Pension ReformSocial Justice and the Reform of Europe's Pension Systems, 13, 2003, 3, 245-263.

SUTOR, Bernard: Politická etika. OIKOYMENH, Praha 1996, 384.

THOVOETHIN, Paul-Sewa - EWALEFOH, Jobson O.: Universal old-age pension: Can Africa overcome it's challenges?, in: Africa's Public Service Delivery \& Performance Review, 6, 2018, 1, 1-7. 
WALKER, Alan: The policy challenges of population aeging. SEDAP Research Paper No $108,2003,50$.

WILLETTS, David: Old Europe? Demographic change and pension reform, CER 2003, 61.

\section{Author}

doc. PhDr. Richard Geffert, Ph. D.

Faculty of Public Administration UPJŠ in Košice

Popradská 66

04011 Košice

Slovac republic

richard.geffert@upjs.sk 